\title{
PERTANGGUNGJAWABAN PIDANA ORANG TUA TERHADAP ANAK SEBAGAI PELAKU TINDAK PIDANA LALU LINTAS
}

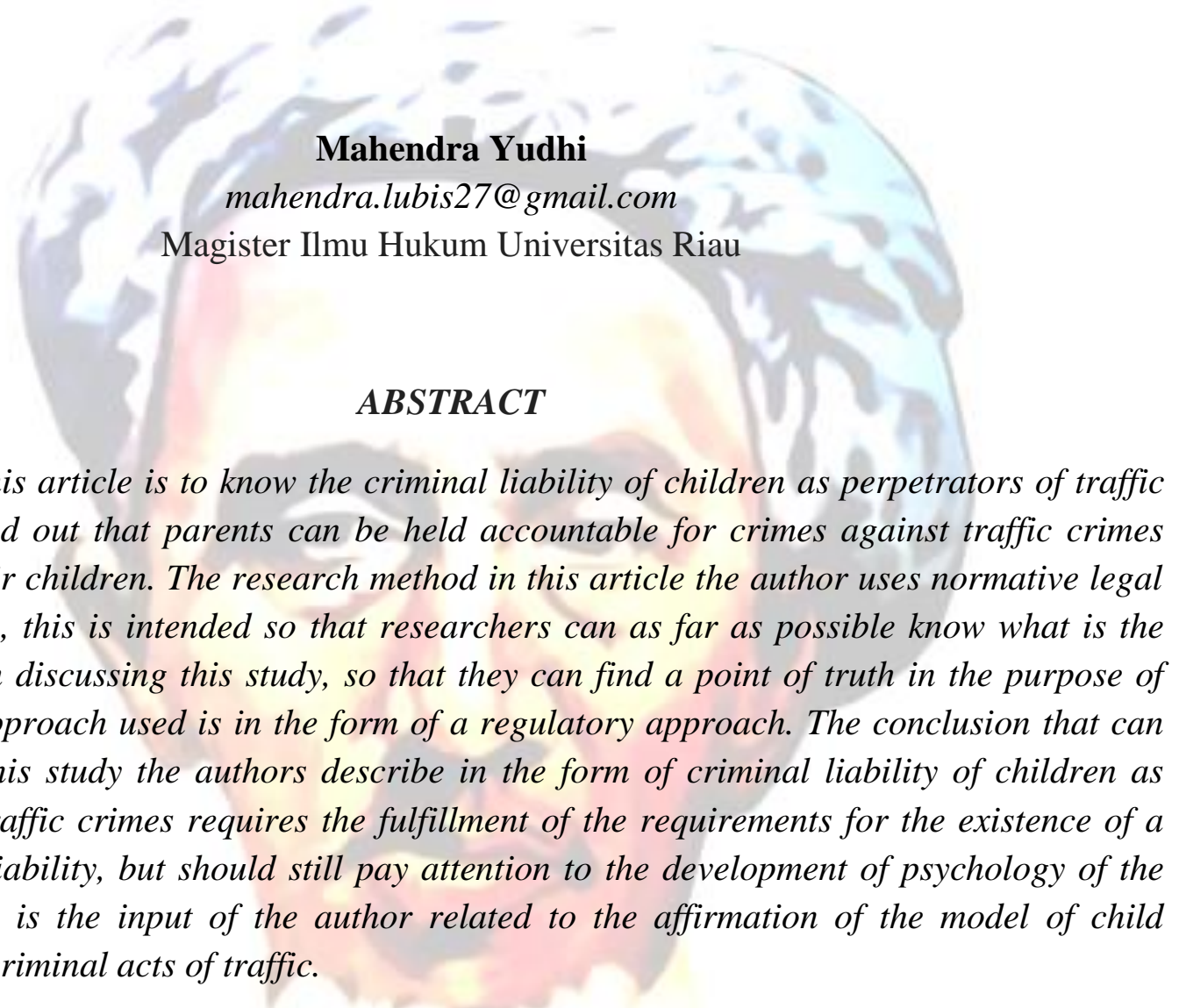

The purpose of this article is to know the criminal liability of children as perpetrators of traffic crimes and to find out that parents can be held accountable for crimes against traffic crimes committed by their children. The research method in this article the author uses normative legal research methods, this is intended so that researchers can as far as possible know what is the measuring tool in discussing this study, so that they can find a point of truth in the purpose of this study. The approach used is in the form of a regulatory approach. The conclusion that can be drawn from this study the authors describe in the form of criminal liability of children as perpetrators of traffic crimes requires the fulfillment of the requirements for the existence of a child's criminal liability, but should still pay attention to the development of psychology of the child's soul. This is the input of the author related to the affirmation of the model of child responsibility in criminal acts of traffic.

Keywords: Children, Traffic Crime, Accountability

\begin{abstract}
ABSTRAK
Tujuan penulisan artikel ini yakni untuk mengetahui pertanggungjawaban pidana terhadap anak sebagai pelaku tindak pidana lalu lintas dan untuk mengetahui orang tua dapat dimintai pertanggungjawaban pidana terhadap tindak pidana lalu lintas yang dilakukan oleh anaknya. Metode penelitian dalam artikel ini penulis menggunakan metode penelitian hukum normatif, hal ini dimaksudkan agar peneliti sejauh mungkin dapat mengetahui apa yang menjadi alat ukur dalam membahas penelitian ini, sehingga dapat mencari setitik kebenaran tujuan dalam penelitian ini. Pendekatan yang digunakan yakni berupa pendekatan peraturan perundang-undangan. Kesimpulan yang dapat diambil dari penelitian ini penulis uraikan berupa pertanggungjawaban pidana anak sebagai pelaku tindak pidana lalu lintas mengharuskan terpenuhinya syarat adanya pertanggungjawaban pidana seorang anak, namun hendaknya tetap memperhatikan perkembangan psikologi jiwa anak. Hal ini menjadi masukan penulis terkait penegasan model pertanggungjawaban anak dalam tindak pidana lalu lintas.
\end{abstract}

Kata Kunci: Anak, Tindak Pidana Lalu Lintas, Pertanggungjawaban. 


\section{PENDAHULUAN}

Indonesia adalah Negara yang berdasarkan atas hukum, sehingga setiap kegiatan manusia atau masyarakat yang merupakan aktivitas hidupnya harus berdasarkan pada peraturan yang ada dan norma-norma yang berlaku dalam masyarakat. Hukum tidak lepas dari kehidupan manusia karena hukum merupakan aturan untuk mengatur tingkah laku manusia dalam kehidupannya karena tanpa adanya hukum kita tidak dapat membayangkan akan seperti apa nantinya Negara kita ini.

Menurut Soedjono dalam Sudarsono, mengatakan bahwa Tujuan hukum adalah untuk melindungi kepentingan itu. Jadi hukum melindungi kepentingan individu di masyarakat dan atau bahkan melindungi masyarakat secara keseluruhan. ${ }^{1}$

Menurut para ahli dan teori tersebut di atas, tujuan hukum dan atau dalam garis besarnya, hukum ini mengabdi pada tujuan Negara yang dalam pokoknya ialah mendatangkan kemakmuran dan kebahagiaan pada rakyatnya, demikian Subekti, adapun Van Apeldoorn dalam Sudarsono, menegaskan bahwa tujuan hukum ialah

${ }^{1}$ Sudarsono, Pengantar Ilmu Hukum, Rineka Cipta, Jakarta, 1991, hal. 113 mengatur pergaulan hidup manusia secara damai. $^{2}$

Sistem peradilan kita masih belum dapat menjamin sebuah proses peradilan yang jujur dan adil. Dimana kadangkala masih terdapat hukuman yang kurang adil atau kesalahan dalam penanganan perkara. Dalam rangka memberikan perlindungan terhadap masyarakat, aparat penegak hukum memiliki peran menanggulangi gangguan yang berupa kejahatan baik dalam bentuk preventif maupun represif. Penegakan hukum yang preventif adalah proses pelaksanaan hukum pidana dalam upaya untuk mencegah terjadinya kejahatan sedangkan penegakan hukum represif merupakan tindakan oleh aparatur penegak hukum jika telah terjadi kejahatan sebagai upaya pelaksanaan hukum pidana yang meliputi penyidikan, penuntutan dan penjatuhan pidana.

Penegak hukum dalam menegakkan hukum harus sesuai dengan hukum dan rasa keadilan dalam masyarakat. Didalam sistem peradilan yang dilaksanakan dan dijalankan saat ini, masih belum dapat dijamin terlaksananya sebuah proses peradilan yang jujur dan adil. Penegakan hukum juga harus diberikan kepada anak sebagai pelaku tindak

${ }^{2}$ Ibid., hal. 114 
pidana, sehingga dengan demikian orang tua dapat mendidik anaknya agar tidak terlibat masalah hukum, karena pada dasarnya Anak merupakan merupakan bagian dari Generasi muda biasanya amat besar perhatiannya terhadap persoalan masyarakat, karena pada usia tersebut mulai tumbuh idealisme (cenderung mengharapkan kesempurnaan).

Terkait persoalan tersebut hal yang sering menjadi perhatian yakni pendidikan baik dari sekolah maupun orang tua sangatlah penting, sebab banyak sekali hal sepele yang sering anak menganggapnya sebelah mata. Perilaku yang tidak sesuai dengan norma atau penyelewengan dapat dicontohkan dalam peristiwa kecelakaan lalu lintas yang terjadi di jalan tol jogorawi yang dilakukan oleh Abdul Qadir Jailani (selanjutnya disebut AQJ) yang merupakan anak seorang musisi terkenal Ahmad Dhani yang telah menghebohkan masyarakat itu. Dimana AQJ yang baru berusia 13 tahun dapat mengemudikan sebuah mobil dengan kecepatan yang cukup tinggi tanpa didampingi seorangpun didalamnya. Bilamana dalam peristiwa yang mengakibatkan 7 orang korban meninggal dunia.

Terkait AQJ yang masih dibawah umur, jelas tidak layak untuk mengendarai
Kendaraan mobil, karena salah satu teradapat persyaratan yang harus dipenuhi oleh pengendara kendaraan bermotor, yang diatur secara jelas dan rinci didalam Undang-Undang No 22 Tahun 2009 Tentang Lalu Lintas dan Angkutan Jalan, dimana didalam Pasal 77 ayat 1 disebutkan bahwa :

"setiap pengemudi kendaraan bermotor wajib memiliki SIM sesuai dengan jenis kendaraan bermotor yang dikemudikan".

Surat Izin Mengemudi adalah Surat bukti registrasi dan identifikasi yang diberikan oleh Polri kepada seseorang yang telah memenuhi persyaratan administrasi, sehat jasmani dan rohani, memahami peraturan lalu lintas dan terampil mengemudikan kendaraan bermotor. Setiap orang yang mengemudikan Kendaraan Bermotor di Jalan wajib memiliki Surat Izin Mengemudi sesuai dengan jenis Kendaraan Bermotor yang dikemudikan. ${ }^{3}$

Melihat peristiwa tersebut yang melibatkan anak sebagai subyek, perlu diketahui bahwa Indonesia telah membentuk peraturan perlindungan anak dalam Negara Kesatuan Republik Indonesia yang sudah dituangkan dalam Undang-Undang Nomor 3 tahun 1997 tentang perlindungan anak yang

3 Pasal 77 ayat (1) Undang-Undang Nomor 22 Tahun 2009 Lalu Lintas dan Angkutan Jalan 
kemudian pemerintah pada tahun 2012 telah mengeluarkan Undang-Undang Nomor 11 Tahun 2012 tentang Sistem Peradilan Pidana Anak yang mana Undang-Undang Nomor 3 Tahun 1997 tersebut sudah dianggap tidak memenuhi kebutuhan hukum masyarakat saat ini, apalagi di dalam Undang-Undang Nomor 11 Tahun 2012 tentang Sistem Peradilan Pidana Anak khususnya dalam hal pertanggung jawaban atas perbuatan pidana yang dilakukan oleh anak dapat diminimalisir dengan upaya diversi, upaya diversi ini merupakan fasilitas pengalihan perkara di luar pengadilan.

Ketentuan Pasal 310 ayat (3) dan ayat (4) Undang-Undang Nomor 22 Tahun 2009 tentang Lalu Lintas dan Angkutan Jalan disebutkan ancaman pidana bagi orang yang mengakibatkan kecelakaan dengan korban meninggal dunia sebagai berikut:

(3) Setiap orang yang mengemudikan Kendaraan Bermotor yang karena kelalaiannya mengakibatkan Kecelakaan Lalu Lintas dengan korban luka berat sebagaimana dimaksud dalam Pasal 229 ayat (4), dipidana dengan pidana penjara paling lama 5 (lima) tahun dan/atau denda paling banyak Rp10.000.000,00 (sepuluh juta rupiah).

(4) Dalam hal kecelakaan sebagaimana dimaksud pada ayat (3) yang mengakibatkan orang lain meninggal dunia, dipidana dengan pidana penjara paling lama 6 (enam) tahun dan/atau denda paling banyak Rp12.000.000,00 (dua belas juta rupiah).

Ancaman pidana yang telah dijelaskan di atas berlaku bagi yang telah dewasa, sedangkan ancaman pidana penjara bagi anak yang melakukan tindak pidana adalah paling lama $1 / 2$ (satu perdua) dari maksimum ancaman pidana penjara bagi orang dewasa. Maka dari rumusan tersebut, dapat dijelaskan bagi anak yang mengemudikan kendaraan bermotor karena kelalaiannya hingga mengakibatkan orang lain meninggal dunia, dipidana dengan pidana penjara setengah dari ancaman pidana bagi orang dewasa (enam tahun), yakni paling lama tiga tahun penjara.

Maka, tujuan diversi adalah mencapai perdamaian antara korban dan anak; menyelesaikan perkara anak di luar proses peradilan; menghindarkan anak dari perampasan kemerdekaan; mendorong masyarakat untuk berpartisipasi; dan menanamkan rasa tanggung jawab kepada anak hal ini dapat dilihat dalam Pasal 6 Undang-Undang Nomor 11 Tahun 2012 tentang Sistem Peradilan Pidana Anak. Proses diversi dilakukan melalui musyawarah dengan 
melibatkan anak dan orang tua/walinya, ditegaskan bahwa pelaku tindak pidana yang korban dan/atau orang tua/walinya, bisa dikenakan pidana adalah:

pembimbing kemasyarakatan, dan pekerja sosial profesional berdasarkan pendekatan keadilan restoratif.

Penjelasan tersebut diatas kita dapat memaknai secara tidak langsung bahwa anak juga mempunyai hak dan peran yang sama pentingnya dengan hak dan peran orang dewasa yang mana hal tersebut merupakan pengakuan yang diberikan oleh negara kepada warga negaranya baik dari anak dalam kandungan sampai dia tua, dan hak anak yang perlu dilindungi adalah hak anak untuk tidak dirampas kemerdekaannya dalam hal anak yang sedang berhadapan dengan hukum.

Pakar Hukum Pidana Universitas Islam Indonesia Mudzakkir menyatakan bahwa asas hukum pidana secara tegas mengatur bahwa tanggung jawab pidana itu tak bisa dialihkan kepada orang lain. Termasuk, jika pengalihan itu diberikan kepada keluarga si pelaku tindak pidana. ${ }^{4}$ Sesuai ketentuan Pasal 55 ayat (1) Kitab Undang-Undang Hukum Pidana (KUHP)

http://www.hukumonline.com/berita/baca/lt522dd6ef db3fa/pakar--tanggung-jawab-pidana-tak-bisadialihkan diakses pada hari Senin, 25 Juli 2018
1. Mereka yang melakukan, yang menyuruh melakukan, dan yang turut serta melakukan perbuatan;

2. Mereka yang dengan memberi atau menjanjikan sesuatu, dengan menyalahgunakan kekuasaan atau martabat, dengan kekerasan, ancaman atau penyesatan, atau dengan memberi kesempatan, sarana atau keterangan, sengaja menganjurkan orang lain supaya melakukan perbuatan.

Selanjutnya Pakar Hukum Pidana Universitas Islam Indonesia Mudzakkir menyatakan, orang tua bisa dimintai pertanggungjawaban sosial kemanusiaan oleh korban. Salah satu bentuknya dengan mekanisme gugatan perdata. "Selain gugatan perdata, orang tua bisa dikenakan beban untuk pidana tambahan".

Karena pelaku dari kecelakaan lalu lintas ini merupakan seorang anak dibawah umur, maka terhadap kerugian yang diderita Korban dapat dimintakan pertanggungjawabannya terhadap orang tua dari si anak, seperti diatur didalam Pasal 1367 Kitab Undang-Undang Hukum Perdata (BW), yaitu:

"Orang tua dan wali bertanggung jawab tentang kerugian, yang disebabkan oleh anak-anak belum dewasa, yang tinggal pada mereka dan 
terhadap siapa mereka melakukan kekuasaan orang tua atau wali"

Dengan kata lain, yang dapat dimintakan pertanggungjawaban atas kerugian adalah orang tua kandung/wali dari si anak, ataupun orang dewasa yang tinggal bersama anak tersebut. Adapun bentuk kerugian yang dapat dimintakan merupakan kerugian Perdata yang disebabkan kecelakaan lalu litas, seperti : biaya pengobatan, biaya ganti rugi kerusakan sepeda motor, sedangkan kerugian dalam bentuk pidana hanya bisa dijalani oleh si anak, sesuai dengan prinsip hukum pidana yaitu Siapa yang melakukan tindak pidana, dia yang harus bertanggung jawab, atau dengan kata lain suatu pemidanaan tidak bisa dialihkan kepada pihak lain, namun karena pelakunya adalah anak, maka yang akan digunakan ialah proses sesuai undang-undang No. 3 tahun 1997 tentang Pengadilan Anak.

Sebagaimana telah penulis jelskan sebelumnya, salah satu kasus yaitu AQJ, secara hukum perbuatan AQJ harus dipertanggungjawabkan secara pidana,karena telah mengakibatkan korban jiwa dalam kasus kecelakaan lalu lintas. Dasar hukum yang diterapkan kepada AQJ adalah Pasal 310 ayat (4) Undang-Undang Nomor 22 tahun 2009 Tentang lalu Lintas Dan Angkutan Jalan jo
Undang-Undang Nomor 3 Tahun 1997 Tentang Pengadilan Anak. Namun ketentuan hukum juga di dalam Pasal 14a dan 14b KUHP, menjadi pengecualian, karena AQJ masih dibawah umur. Sedangkan untuk Ahmad Dhani sebagai orang tua dapat melakukan ganti rugi apabila diterapkan pidana tambahan sesuai pasal 23 ayat (3) Undang-Undang Nomor 3 Tahun 1997 Tentang Pengadilan Anak.

Melihat tindak pidana yang dilakukan oleh anak tersebut tidak cukup hanya pertanggungjawan ganti kerugian saja yang dibebankan kepada orang tua, dibutuhkan pertangungjawaban orang tua terhadap tindak pidana yang dilakukan oleh anaknya, karena pada dasarnya anak sebaiknya tidak boleh dihukum. Melihat karena kelalaian orang tualah sianak melakukan tindak pidana.

Penelitian ini juga berangkat dari pengalaman dan kekhawatiran penulis sebagai penegak hukum melihat anak di bawah umur dengan gampang mengendarai kendaraan bermotor di jalan raya, padahal seorang anak dibawah umur seharusnya tidak dibenarkan mengendarai kendaraan, selain karena membahayakan nyawanya dan orang lain, hal tersebut bertentangan dengan Undang-Undang 
Nomor 22 Tahun 2009 tentang Lalu Lintas dan Angkutan Jalan. Maka, seharusnya orang tua sebagai wali dan penanggung jawab si anak seharusnya memiliki rasa tanggung jawab dan menghindari agar terjadinya kecelakaan atau hal lain yang tidak diinginkan yang diakibatkan karena si anak mengendarai motor.

\section{METODE PENELITIAN}

Metode penelitian yang penulis gunakan dalam penelitian ini adalah penelitian hukum normatif atau yang dikenal dengan istilah Legal research..$^{5}$ menekankan pada studi dokumen dalam penelitian kepustakaan untuk mempelajari data sekunder di bidang hukum yang berhubungan dengan permasalahan dan tujuan penelitian ini. Menurut Bagir Manan, penelitian normatif adalah penelitian terhadap kaedah dan asas hukum yang ada. ${ }^{6}$ Menurut Haryono, suatu penelitian normatif tentu harus mengunakan pendekatan perundang-undangan, karena yang akan diteliti adalah berbagai aturan hukum

5 Peter Mahmud Marzuki, Penelitian Hukum , Edisi revisi, Kencana, Jakarta, 2013, hlm.47

${ }^{6}$ Soerjono Soekanto dan Sri Mamuji, Penelitian hukum Normatif: Suatu tinjauan Singkat,Jakarta: Raja Grafindo Persada, 1994, hal. 13 yang menjadi fokus sekaligus tema sentral suatu penelitian. ${ }^{7}$

Dalam penelitian hukum normatif ini menggunakan sumber Data diambil dari bahan Hukum Primer, yang diperoleh peneliti dari berbagai perpustakaan, Peraturan perundangundangan, yurisprudensi yang berkaitan dengan permasalahan penelitian ini, yang terdiri dari:

a. Bahan Hukum Primer, Yaitu Bahan Hukum Primer adalah bahan yang berupa Peraturan perundang-undangan yang masih menjadi Hukum Positif yaitu UUD 1945, Undang-Undang Nomor 23 Tahun 2002 Tentang Anak, Undang-Undang Nomor 3 Tahun 1997 Tentang Pengadilan Anak, Undang-Undang Nomor 22 Tahun 2009 Tentang lalu Lintas dan Angktan Jalan, Kitab Undang Hukum Perdata, Kitab Undang Hukum Pidana.

b. Bahan Hukum Sekunder, yaitu bahan hukum yang memberikan penjelasan bahan hukum primer, yaitu yang dapat berupa Buku-buku yang ditulis oleh para ahli hukum, teori Hukum, hasil-hasil penelitian, hasil karya ilmiah hukum.

\footnotetext{
${ }^{7}$ Johnny Ibrahim, Teori Dan MetodologiPenelitan Hukum Normatif, Bayumedia Publisshing, Malang, 2010, hal. 302
} 
c. Bahan Hukum Tertier, yaitu bahan hukum yang memberikan petunjuk atau penjelasan guna menunjang pembahasan terhadap bahan hukum primer dan sekunder, misalnya Kamus bahasa Indonesia, Bahasa Asing, ensiklopedi, dan lainnya.

Dalam pengumpulan data untuk penelitian hukum normatif digunakan metode kajian kepustakaan. Dalam hal ini peneliti harus cermat dan tepat untuk menemukan data yang terdapat baik dalam peraturan-peraturan maupun dalam literatur-literatur yang memiliki hubungan dengan permasalahan yang diteliti yakni mengenai analisis pertanggungjawaban pidana orang tua terhadap anak sebagai pelaku tindak pidana lalu lintas.

Tahap-tahap pengumpulan data melalui studi pustaka adalah sebagai berikut :

a. Melakukan inventarisasi hukum positif dan bahan-bahan hukum lainnya yang relevan degan objek penelitian.

b. Melakukan penelusuran kepustakaan melalui, artikel- artikel media cetak maupun elektronik, dokumen-dokumen pemerintah dan peraturan perundangundangan. c. Mengelompokan data-data yang relevan dengan permasalahan.

d. Menganalisis data-data yang relevan tersebut untuk menyelesaikan masalah yang menjadi objek penelitian. ${ }^{8}$

Melalui proses penelitian, diadakan analisis dan Kontruksi data yang telah dikumpulkan dan diolah. Oleh karena itu, metodologi penelitian yang diterapkan harus sesuai dengan ilmu pengetahuan yang menjadi induknya. $^{9}$

Dalam penelitian ini data dapat dianalisis secara kualitatif. Analisis kualitatif biasanya data dianalisis dengan tidak menggunakan statistik atau matematika ataupun yang sejenisnya, namun cukup dengan menguraikan secara deskriptif dari data yang telah diperoleh. Dalam penetapan metode analisis ini disesuaikan dengan kategori data dan keinginan penulis selaku peneliti.

Dalam menarik kesimpulan penulis menggunakan metode berfikir deduktif. Metode berfikir deduktif ialah cara berfikir yang menarik suatu kesimpulan dari suatu

8 Ronny Hanitijo Soemitro, Metedologi Penelitian Hukum dan Jurimetri, Ghalia Persada Jakarta, 1990, hal. 63

9 Zainuddin Ali, Metode Penelitian Hukum, Sinar Grafika, Jakarta, 2010, hlm. 17 
pernyataan atau dalil yang bersifat umum menjadi suatu pernyataan atau kasus yang bersifat khusus, sedangkan metode berfikir induktif ialah cara berfikir yang menarik suatu kesimpulan dari suatu pernyataan atau dalil yang bersifat khusus menjadi suatu pernyataan atau kasus yang bersifat umum.

\section{HASIL PENELITIAN}

\section{A. Pertanggungjawaban Pidana terhadap} Anak Sebagai Pelaku Tindak Pidana

\section{lalu Lintas}

Anak adalah karunia Tuhan Yang Maha Esa, yang harus dijaga karena dalam dirinya melekat harkat, martabat, dan hak-hak sebagai manusia yang harus dijunjung tinggi. Anak adalah masa depan bangsa dan generasi penerus cita-cita bangsa, sehingga setiap anak berhak atas kelangsungan hidup, tumbuh, dan berkembang, berpartisipasi serta berhak atas perlindungan dari tindak kekerasan dan diskriminasi serta hak sipil dan kebebasan. ${ }^{10}$

Anak sebagai bagian dari generasi muda merupakan salah satu sumber daya manusia yang memiliki potensi untuk tercapainya cita-cita perjuangan bangsa. Oleh sebab itu anak berhak atas perlindungan dari lingkungan hidup yang dapat membahayakan

10 Poerwadarminta W.J.S, Kamus Umum Bahasa Indonesia, Balai Pustaka, Jakarta, 2003, hal. 11 atau menghambat pertumbuhan dan perkembangannya dengan wajar termasuk mereka yang menjadi korban tindak kekerasan, anak seperti ini perlu mendapat perlindungan hukum. Untuk melaksanakan pembinaan dan memberikan perlindungan terhadap anak diperlukan dukungan yang baik menyangkut kelembagaan maupun perangkat hukum yang lebih memadai.

Dikemukakan oleh Ter Haar bahwa saat seseorang menjadi dewasa ialah saat ia (laki-laki atau perempuan) sebagai orang yang sudah berkawin, meninggalkan rumh ibu bapaknya atau ibu bapak mertuanya untuk berumah lain sebagai laki-bini muda merupakan keluarga yang berdiri sendiri. ${ }^{11}$

Pasal 45 KUHP, mendefinisikan anak yang belum dewasa apabila belum berumur 16 (enam belas) tahun. Oleh karena itu, apabila ia tersangkut dalam perkara pidana hakim boleh memerintahkan supaya si tersalah itu dikembalikan kepada orang tuanya; walinya atau pemeliharanya dengan tidak dikenakan suatu hukuman. Atau memerintahkannya supaya diserahkan kepada pemerintah dengan tidak dikenakan sesuatu hukuman. Ketentuan pasal 35, 46 dan 47

\footnotetext{
${ }^{11}$ Ter Haar dalam Syafiyudin Sastrawujaya, Beberapa Masalah Tentang Kenakalan Remaja, PT. Karya Nusantara, Bandung, 1977, hal. 18.
} 
KUHP ini sudah dihapuskan dengan lahirnya Undang-undang No. 3 Tahun 1997.

Anak menurut bahasa adalah keturunan kedua sebagai hasil antara hubungan pria dan wanita. Dalam konsideran Undang-Undang No. 23 Tahun 2002 tentang perlindungan anak, dikatakan bahwa anak adalah amanah dan karuni Tuhan Yang Maha Esa, yang dalam dirinya melekat harkat dan martabat sebagai manusia seutuhnya. ${ }^{12}$

A.Z. Abidin mengusulkan pemakaian istilah "Perbuatan Kriminal", karena "Perbuatan Pidana" yang dipakai oleh Moeljatno itu juga kurang tepat, karena dua kata benda bersambungan yaitu "Perbuatan" dan "Pidana", sedangkan tidak ada hubungan logis antar keduanya. Jadi, meskipun tidak memiliki istilah yang sama,tetapi keduanya dipengaruhi oleh istilah yang dipakai di Jerman, yaitu "Tat" (Perbuatan) atau "Handlung" (Tindakan). ${ }^{13}$ Menurut Wirjono Prodjodikoro, "tindak pidana berarti suatu perbuatan yang pelakunya dapat dikenakan hukuman pidana. ${ }^{14}$

\footnotetext{
${ }^{12}$ M. Nasir Djamil, Anak Bukan Untuk Dihukum, Sinar Grafika, Jakarta Timur, 2013. hal. 8

13 Andi Hamzah, Asas-Asas Hukum Pidana, Rineka Cipta, Jakarta, 1997 hal. 85

${ }^{14}$ Wirjono Projodikoro, Asas-Asas Hukum Pidana di Indonesia. Bandung: Refika Aditama, 2003, hal. 50
}

Menurut G.A. van Hamel, sebagaimana yang diterjemahkan oleh Moeljatno, "strafbaar Feit adalah kelakuan orang (menselijke gedraging) yang dirumuskan dalam wet, yang bersifat melawan hukum, yang patut dipidana (strafwaardig) dan dilakukan dengan kesalahan. ${ }^{15}$

Pengertian anak secara khusus dapat diartikan menurut Undang-Undang Nomor 23 Tahun 2002 tentang Perlindungan Anak Pasal 1 ayat (1), bahwa dimaksud dengan anak adalah seseorang yang belum berusia 18 (delapan belas) tahun, termasuk anak yang masih dalam kandungan.Anak sebagai generasi penerus dan pengelola masa depan bangsa perlu dipersiapkan sejak dini melalui pemenuhan hak-haknya yakni hak untuk hidup, tumbuh, berkembang, dan berpartisipasi secara wajar sesuai dengan harkat dan martabat kemanusiaan, serta mendapat perlindungan dari kekerasan dan diskriminasi.

Menurut Wirjono Prodjodikoro tindak pidana adalah pelanggaran normanorma dalam tiga bidang hukum lain, yaitu Hukum Perdata, Hukum Ketatanegaraan, dan Hukum Tata Usaha Pemerintah, yang oleh

15 Moeljatno, Asas-Asas Hukum Pidana, Renika Cipta, Jakarta, 2002, hal. 56 
pembentuk undang-undang ditanggapi dengan suatu hukum pidana, maka sifat-sifat yang ada dalam suatu tindak pidana adalah sifat melanggar hukum, karena tidak ada suatu tindak pidana tanpa sifat melanggar hukum. ${ }^{16}$

Menurut Simons dalam buku Roni Wiyanto mendefinisikan tindak pidana sebagai suatu perbuatan (handeling) yang diancam dengan pidana oleh undang-undang, bertentangan dengan hukum (onrechtmatig) dilakukan dengan kesalahan (schuld) oleh seseorang yang mampu bertanggung jawab. Rumusan pengertian tindak pidana oleh simons dipandang sebagai rumusan yang lengkap karena akan meliputi :

a. Diancam dengan pidana oleh hukum.

b. Bertentangan dengan hukum.

c. Dilakukan oleh seseorang dengan kesalahan (schuld).

d. Seseorang itu dipandang bertanggung jawab atas perbuatannya. ${ }^{17}$

Kedudukan pelaku (pleger) dalam

Pasal 55 KUHP, janggal karena pelaku bertangggungjawab atas perbuatannya (pelaku tunggal) dapat dipahami:

16 Wirjono Prodjodikoro, Tindak-Tindak Pidana Tertentu di Indonesia, Bandung, Refika Aditama, 2003, hal.1

17 Roni Wiyanto, Asas-asas Hukum Pidana Indonesia, Bandung, C.V Mandar Maju, 2012, hal. 160 a. Pasal 55 menyebut siapa-siapa yang disebut sebagai pembuat, jadi pleger masuk didalamnya.

b. Mereka yang bertanggung jawab adalah yang berkedudukan sebagai pembuat.

Menurut Pasal 1 Huruf 2 UndangUndang Nomor 3 Tahun 1997 tentang Pengadilan Anak, terdapat dua kategori perilaku anak yang dapat membuat seorang anak berhadapan dengan hukum yakni status offences dan criminal offences. Status Offence adalah perilaku kenakalan anak yang apabila dilakukan oleh orang dewasa tidak dianggap sebagai kejahatan, seperti tidak menurut, membolos sekolah atau kabur dari rumah; sedangkan Criminal Offence adalah perilaku kenakalan anak yang apabila dilakukan oleh orang dewasa dianggap kejahatan atau pelanggaran hukum.

Namun terlalu extrim apabila tindak pidana yang dilakukan oleh anak-anak disebut dengan kejahatan, karena pada dasarnya anakanak memiliki kondisi kejiwaan yang labil, proses kemantapan psikis menghasilkan sikap kritis, agresif dan menunjukkan tingkah laku yang cenderung bertindak mengganggu ketertiban umum. Hal ini belum dapat dikatakan sebagai kejahatan, melainkan kenakalan yang ditimbulkan akibat dari 
kondisi psikologis yang tidak seimbang dan si pelaku belum sadar dan mengerti atas tindakan yang telah dilakukannya. ${ }^{18}$

Ada beberapa faktor penyebab yang paling mempengaruhi timbulnya kejahatan anak, yaitu: ${ }^{19}$

a. Faktor lingkungan

b. Faktor ekonomi/ sosial

c. Faktor psikologis

\section{Hakikatnya anak tidak dapat} melindungi diri sendiri dari berbagai macam tindakan yang menimbulkan kerugian mental, fisik, sosial dalam berbagai bidang kehidupan dan penghidupan. Anak harus dibantu oleh orang lain dalam melindungi dirinya, mengingat situasi dan kondisinya, khususnya dalam pelaksanaan peradilan pidana anak yang asing bagi dirinya. Anak perlu mendapat perlindungan dari kesalahan penerapan peraturan perundang-undangan yang diperlakukan terhadap dirinya, yang menimbulkan kerugian mental, fisik, dan sosial. Perlindungan anak dalam hal ini

${ }^{18}$ Wagiati Soetodjo, Hukum Pidana Anak, Bandung: PT Refika Aditama, 2006, hal. 12

${ }^{19}$ A.Syamsudin Meliala dan E.Sumaryono, Kejahatan Anak Suatu Tinjauan dari Psikologis dan Hukum, Yogyakarta, Liberty, 1985, hal. 31 disebut perlindungan hukum/yuridis (legal protection). ${ }^{20}$

Perbuatan anak-anak yang menyebabkan terjadinya korban dalam kecelakaan lalu lintas banyak disebabkan oleh faktor psikologi anak yang masih labil. Dalam masa pertumbuhan dan perkembangannya seorang anak selalu ingin mencoba sesuatu yang baru. Salah satunya adalah seorang anak yang ingin mencoba untuk mengemudikan kendaraan bermotor. Mengemudikan kendaraan bermotor membutuhkan waktu latihan yang sangat panjang. Walaupun pada saat latihan seorang anak dapat mengemudikan kendaraan bermotor dengan baik belum tentu anak tersebut bisa mengendarai kendaraan bermotor dengan baik dijalan yang sesungguhnya. Ramainya arus lalu lintas serta kondisi psikologi anak yang belum stabil menyebabkan anak tersebut menjadi gugup dan takut serta dapat melakukan kesalahan yang mengakibatkan terjadinya kecelakaan lalu lintas.

Kecelakaan lalu lintas yang dilakukan seorang anak dapat menyebabkan kematian korban. Hal ini dapat terjadi karena

\footnotetext{
20 Maidin Gultom, Perlindungan Hukum Terhadap Anak Dalam Sistem Peradilan Pidana Anak Di Indonesia, PT. Refika Aditama, Bandung, 2010, hal. 2
} 
factor kelalaian dari anak tersebut serta anak belum memahami dan belum mengerti aturan dan etika berlalu lintas yang baik. Faktor kelalaian menjadi penyebab karena anak tidak berhati-hati dalam mengemudikan kendaraan serta kondisi psikologi anak yang belum stabil. Seorang anak secara hukum belum memenuhi syarat untuk mengemudikan kendaraan bermotor. Seorang anak sebelum mencapai batas usia tertentu tidak diizinkan untuk mengemudikan kendaraan bermotor. Seorang anak sebelum mencapai batas usia tertentu untuk mengemudikan kendaraan bermotor harus diberi pelajaran tentang aturan dan etika berlalu lintas yang baik sesuai dengan aturan yang berlaku. Pelajaran tentang aturan dan etika berlalu lintas yang baik dan benar sangat penting dipelajari dan dipahami oleh seorang anak. Hal tersebut bertujuan agar seorang anak dapat lebih berhati-hati dalam berlalu lintas hingga tidak terjadi kecelakaan lalu lintas yang dapat mengakibatkan kematian koban.

Seorang anak yang terlibat kecelakaan lalu lintas yang menyebabkan kematian korban harus bertanggung jawab atas perbuatannya tersebut. Pertanggung jawaban seorang anak harus berdasarkan peraturan perundang-undangan yang berlaku sebab perbuatan anak tersebut dikategorikan sebagai perbuatan pidana. Perbuatan pidana yang dilakukan oleh anak tersebut adalah kecelakaan lalu lintas, belum memenuhi syarat untuk mengemudikan kendaraan bermotor serta mengakibatkan kematian pada korban. Anak yang terlibat dalam kecelakaan lalu lintas yang menyebabkan kematian korban harus mempertanggung jawabkan perbuatannya berdasarkan peraturan perundang-undangan yang berlaku. Seorang anak harus bertanggung jawab atas kematian korban dan apabila anak tersebut terbukti bersalah dapat dijatuhi sanksi pidana atas perbuatan yang telah dilakukannya.

Kecelakaan lalu lintas oleh seorang anak yang menimbulkan kecelakan sehingga menyebabkan kematian korban merupakan perbuatan yang sangat disayangkan oleh semua pihak. Hal ini disebabkan karena anak adalah amanah sekaligus karunia Tuhan Yang Maha Esa, yang senantiasa kita jaga karena didalam dirinya melekat harkat, martabat, dan hak-hak sebagai manusia yang harus dijunjung tinggi.

Diantara tindak pidana dengan pelaku anak yang menarik perhatian publik adalah kenakalan anak yang menjurus pada tindak pidana kecelakaan lalu lintas. Hal ini 
tidak hanya dipicu oleh kejadian kecelakaan lalu lintas yang menimpa AQJ anak musisi Ahmad Dani yang disebut-sebut sebagai "sopir maut" yang masih berusia 13 (tiga belas) tahun namun diperbolehkan mengenadarai mobil yang mengakibatkan kecelakaan lalu lintas pada tanggal 8 September 2013 di Tol Jagorawi dengan korban 7 (tujuh) orang meninggal dunia dan lainnya luka-luka, tetapi disebabkan kasus serupa banyak terjadi di daerah-daerah lain.

Penjelasan Undang-Undang Nomor 22 Tahun 2009 tentang Lalu Lintas dan Angkutan Jalan, terdapat alasan mendasar mengenai harus dipenuhinya syarat usia untuk mendapatkan Surat Izin Mengemudi (SIM), yaitu untuk menjamin terwujudnya penyelenggaraan lalu lintas dan angkutan jalan yang memenuhi standar keselamatan dan keamanan. Sedangkan untuk menangani masalah kecelakaan lalu lintas, pencegahan kecelakaan dilakukanmelalui partisipasi para pemangku kepentingan, pemberdayaan masyarakat, penegakanhukum dan kemitraan global. Tersedianya sanksi pidana bagi pelanggar, dimaksudkan agar dapat menimbulkan efek jera bagi pelaku pelanggaran dengan tidak terlalu membebani masyarakat.
Salah satu penyebab terjadinya tindak pidana kecelakaan lalu lintas khususnya bagi anak adalah tidak dipenuhinya syaratsyarat berlalu lintas sesuai ketentuan hukum yang berlaku, diantaranya memiliki SIM (Surat Izin Mengemudi) dan keterampilan mengendarai kendaraan bermotor. Untuk mendapatkan Surat Izin Mengemudi (SIM), pengemudi harus terlebih dahulu memenuhi persyaratan yang terdiri dari, persyaratan usia, administratif, kesehatan, dan lulus ujian. Hal ini seringkali diabaikan oleh para orang tua yang memiliki anak dan sudah berani mengendarai kendaraan bermotor. UndangUndang Lalu Lintas dan Angkutan Jalan telah mengatur syarat-syarat tersebut dalam Pasal 81 sebagaimana telah disebutkan diatas.

\section{B. Pertanggungjawaban Pidana Orang Tua terhadap Tindak Pidana lalu lintas yang Dilakukan Oleh Anak}

Tanggung jawab pemerintah dan negara dalam usaha perlindungan hak anak, termasuk hak Anak yang Berkonflik dengan Hukum sudah diatur oleh Undang Undang Perlindungan Anak. Karena anak berbeda dengan orang dewasa dan masih dalam proses perkembangan yang sangat perlu mendapat didikan yang tepat, anak memiliki hak khusus yang harus didapatkan ketika melakukan 
tindakan kriminal dan berurusan dengan hukum.

Orang tua yang merupakan sarana pembelajaran primer dan paling penting bagi anak, memiliki peran utama dalam pembentukan kepribadian dan perilaku anak. Dari orang tua lah anak mendapatkan contoh utama dalam berperilaku. Sesuai teori Social Learning, anak akan melakukan proses modelling perilaku dari orang tua. Seperti kata peribahasa, "Buah jatuh tidak jauh dari pohonnya". Jika orang tua memberikan contoh berperilaku yang sopan, hangat, dan perilaku baik lainnya, maka kemungkinan besar anak pun akan memiliki perilaku yang sama. Begitupun jika orang tua memiliki perilaku yang kasar, suka membentak, malas, dan perilaku buruk lainnya, maka kemungkinan besar anak pun akan meniru perilaku buruk tersebut.

Ketika anak sudah terlibat tindak kriminal dan berkonflik dengan hukum, maka orang tua tetap harus bisa memberikan dukungan moralnya kepada anak dan tidak memberikan label negatif padanya. Untuk memberikan dukungan moral bagi anak yang berkonflik dengan hukum, salah satu usaha langsung yang dapat dilakukan orang tua adalah dengan berkomunikasi dan interaksi di setiap kesempatan yang ada dalam kehidupan sehari-hari. Komunikasi dan interaksi orang tua dengan anak sangat penting. Sesuai teori interaksionisme simbolik, jika interaksi yang berlangsung antara orang tua dan anak baik, maka pemaknaan anak terhadap orang tua pun akan positif, dan begitupun sebaliknya. Orang tua yang memiliki komunikasi dan interaksi yang hangat dengan anaknya juga memberikan keuntungan bagi orang tua agar bisa membangun komunikasi yang terbuka dan mendeteksi sejak awal jika anak melakukan tindakan yang melanggar norma masyarakat. Komunikasi yang hangat juga efektif untuk memberikan pendidikan nilainilai benar yang berlaku di masyarakat agar anak tidak bingung bagaimana tuntutan masyarakat terhadap dirinya sebagai individu.

Selain menjalin komunikasi, pengawasan orang tua terhadap anak juga berperan penting dalam menjaga perilaku anak tetap dalam kewajaran norma. Jika pengawasan dari orang tua dan keluarga terhadap anak lemah, maka hal ini dapat menjadi salah satu penyebab anak melakukan tindakan kriminal, sehingga akan berakibat tingginya angka kriminalitas pada anak.

Sistem Peradilan Pidana Anak adalah seluruh proses penyelesaian perkara anak yang 
berhadapan dengan hukum, yang dimulai berhadapan dengan hukum tidak dengan tahap penyelidikan ke tahap terstigmatisasi akibat proses peradilan yang pembimbingan setelah menjalani pidana serta harus dijalaninya. Penggunaan mekanisme mengutamakan kepentingan yang terbaik bagi diversi tersebut diberikan kepada para anak. Pada hakikatnya dalam ranah Hukum penegak hukum (polisi, jaksa, hakim, lembaga Pidana, Pertanggungjawaban terhadap lainnya) dalam menangani pelanggarperbuatan pidana hanya dilakukan oleh sipelaku tindak pidana tersebut berdasarkan asas yang berlaku dalam Hukum Pidana yaitu "Nullu Poena Sine Crimen" (tiada pidana tanpa perbuatan pidana), asas tersebut dipahami bahwa untuk dibebankannya seseorang dengan suatu tanggungjawab hukum harus telah melakukan tindak pidana. Dalam peradilan yang memproses perkara anak, tidak sepenuhnya pertanggungjawaban pidana dilakukan oleh anak, dalam praktik telah terjadi peralihan pertanggungjawaban tersebut dimana seharusnya anak yang mengemban beralih ke orang tua dari si anak yang mempunyai posisi sebagai pelaku, melalui proses diversi.

\section{Pasal 1 angka 7 Undang-Undang} Sistem Peradilan Pidana Anak menyebutkan diversi adalah pengalihan perkara anak dari proses peradilan pidana ke proses di luar peradilan pidana. Undang-Undang Sistem Peradilan Pidana Anak mengatur tentang diversi yang berfungsi agar anak yang pelanggar hukum yang melibatkan anak tanpa menggunakan pengadilan formal. Penerapan diversi tersebut dimaksudkan untuk mengurangi dampak negatif keterlibatan anak dalam suatu proses peradilan. ${ }^{21}$

Hubungan antara diversi dan pertanggungjawaban orang tua, dalam hal ini dapat diketahui bahwa tujuan dari diversi yang disebutkan dalam Pasal 6 Undang-undang Sistem Peradilan Pidana Anak, yaitu:

a. Mencapai perdamaian antara korban dan anak;

b. Menyelesaikan perkara anak diluar proses peradilan;

c. Menghindarkan anak dari perampasan kemerdekaan;

d. Mendorong masyarakat untuk berpartisipasi; dan

e. Menanamkan rasa tanggungjawab kepada anak. $^{22}$

\footnotetext{
${ }^{21}$ Pasal 1 angka 7 Undang-Undang Nomor 11 Tahun 2012 tentang Sistem Peradilan Pidana Anak

${ }^{22}$ Pasal 6 Undang-Undang Nomor 11 Tahun 2012 Tentang Sistem Peradilan Pidana Anak.
} 
Pelaksanaan diversi harus adanya tidak mungkin mengalihkan persetujuan dari si anak sebagai pelaku pertanggungjawaban kepada orang lain. Dapat kejahatan, orang tua atau walinya serta dilihat di dalam Asas pokok di dalam hukum memerlukan kerja sama dan peran masyarakat pidana, khususnya di dalam sistem Eropa sehubungan dengan adanya program seperti: Continental atau Civil Law, maka pengawasan bimbingan, pemulihan, serta ganti rugi kepada korban. Dan proses diversi tersebut wajib memerhatikan kepentingan korban, kesejahteraan dan tanggung jawab anak, penghindaran stigma negatif, penghindaran pembalasan, keharmonisan masyarakat, dan kepatutan, kesusilaan, dan ketertiban umum. $^{23}$

Undang-Undang Sistem Peradilan Pidana Anak yaitu Undang-Undang Nomor 11 Tahun 2012 menjelaskan bahwa anak yang berhadapan dengan hukum adalah anak yang berkonflik dengan hukum, anak yang menjadi korban tindak pidana, dan anak yang menjadi saksi tindak pidana. Anak yang berkonflik dengan hukum yang selanjutnya disebut anak adalah anak yang telah berumur 12 (dua belas) tahun, tetapi belum berumur 18 (delapan belas) tahun dan diduga melakukan tindak pidana.

Pola pertanggungjawaban pidana di dalam perundang-undangan pada dasarnya

pertanggungjawaban tersebut adalah pertanggungjawaban langsung berdasarkan Undang-Undang atau yang sering disebut dengan strict liability. ${ }^{24}$

Indonesia yang semula diklaim sebagai penganut sistem hukum eropa kontinental sebagai akibat dari bekas jajahan Belanda. Namun sejak masa penjajahan keberadaan hukum yang hidup di dalam masyarakat tetap diakui dan hukum yang hidup di dalam masyarakat (living law) tersebut tentu tidak terlepas dari keyakinan atau agama, sehingga hukum islam juga sangat dijunjung tinggi oleh masyarakat Indonesia. Dengan demikian wajah hukum di Indonesia sebenarnya cerminan dari berbagai sistem hukum tersebut. $^{25}$

Prof. Dr. Muladi dan Dr. Barda Nawawi mengatakan bahwa tujuan dan dasar pemikiran mengenai peradilan anak adalah masalah kesejahteraan atau kepentingan anak. Diperlukan pendekatan khusus dalam

${ }^{23}$ Chairul Bariah, Mohd. Din, Mujibussalim Syiah Kuala Law Journal : Vol. 1, No.3 Desember 2017, hal. 79

\footnotetext{
${ }^{24}$ Ibid, hal. 80

${ }^{25}$ Ibid
} 
menangani masalah hukum dan peradilan anak, yaitu:

a. Anak yang melakukan tindak pidana/kejahatan (juvenile offender) janganlah dipandang sebagai seorang penjahat (kriminal) tetapi harus dipandang sebagai seorang yang memerlukan bantuan, pengertian dan kasih sayang;

b. Pendekatan yuridis terhadap anak hendaknya lebih mengutakan pendekatan persuasive-edukatif yang berarti sejauh mungkin menghindari proses hukum yang semata-mata bersifat menghukum, yang bersifat degradasi mental dan penurunan semangat (discouragement) serta menghindari proses stigmatisasi yang dapat menghambat proses perkembangan, kematangan dan kemandiriaN anak dalam arti yang wajar. ${ }^{26}$

Anak tidak seharusnya dihadapkan pada sistem peradilan jika ada cara yang yang lebih tidak menekan atau restriktif untuk menangani perbuatan yang melawan hukum. Sehingga karenanya sudah saatnya ada suatu perubahan pola pikir mengenai anak yang melakukan tindak pidana, anak tersebut harus selalu diposisikan sebagai korban dan bukan

26 Muladi dan Barda Nawawi Arief, Bunga Rampai Hukum Pidana, Bandung: Alumni, 1992, hal. 109. pelaku sebab anak yang melakukan tidak berdiri sendiri, melainkan karena diakibatkan oleh masalah diluar kemampuan anak itu sendiri misalnya masalah ekonomi, sosial, budaya dan lingkungan mereka berada. ${ }^{27}$

Tindak pidana yang dilakukan oleh anak tidak memenuhi unsur suatu kesalahan pertama dikarenakan ketidakmampuannya untuk dimintakan pertanggungjwaban padanya dengan keadaan psikologi yang masih labil dan perbuatannya bukan berdasarkan pertimbangan yang matang, disamping itu juga berbuatnya seorang anak merupakan akibat dari kealpaan orang lain dalam hal ini orang tuanya. Mengenai pertanggungjawaban selain dikenal istilah liability juga dikenal istilah responsibility yang konteks pertanggungjawaban meliputi hal-hal yang dapat dipertanggungjawabkan atas suatu kewajiban, keputusan, kemampuan atau kecakapan dan juga terhadap kewajiban undang-undang yang dilaksanakan.Peralihan pertanggungjawaban anak yang beralih kepada orang tua dikarenakan posisi anak bukan sebagai subjek dalam proses dan tidak

27 Ira M.Schwartz dan laura Preiser. "Diversion and Juvenile Justice: Can We Ever Get It Right? " dalam Restorative Justice on Trial : Pitfalls and Potentials of Victim Offender Mediation International Research Perspectives, eds Messmer,H dan Otto, H.U , Kluwer Academic Publischers, Dordrecht, 1992, hal 281. 
memenuhi unsur dari suatu kesalahan dalam konteks hukum pidana walaupun secara nyata ia telah melakukan tindak pidana, namun tidak dapat dimintakan pertanggungjawaban pidana serta perbuatan pidananya tersebut dapat dianalisir sebagai kesalahan dari orang tuanya baik karena kelalaian atau kesengajaan, oleh karena itu dalam hal ini posisi anak sebagai korban.

Meskipun anak yang terlibat dengan hukum pada kenyataannya sebagai pelaku, anak juga dikategorikan sebagai korban, maksud korban dalam hal ini adalah korban dari kelalaian orang tuanya yang menyebabkan anak tersebut melakukan tindak pidana. Walaupun di dalam konsep dasar hukum pidana menyebutkan orang yang melakukan tindak pidana lah yang dapat mempertanggung jawabkan perbuatannya, namun dalam hal ini anak yang dianggap sebagai korban dari kelalaian orang tuanya menyebabkan orang tua juga ikut bertanggung jawab atas tindak pidana yang telah dilakukan anaknya.

Selayaknya orang tua sebagai subjek yang bermartabat terhadap anak bisa dikategorikan telah menyalahgunakan kekuasaan atau martabatnya tersebut, dalam penjelasan Pasal 55 ayat (2) KUHP makna kekuasaan tidak terbatas pada jabatan negeri bisa juga kekuasaan antara bapak dan anak, majikan dan buruh, saat mana orang tua menyalah gunakan kekuasaannya terhadap anak anak yang dibawah penguasaannya dan juga memberi kesempatan dalam artian membiarkan sebagaimana contoh kasus diatas dimana seorang anak perempuan tidak menggunakan jilbab, sedangkan aturan melarang perbuatan tersebut, namun orang tua membiarkan, dan memberi kesempatan bahkan sarana untuk mengendarai kendaraan yang seharusnya berdasarkan aturan hukum dalam batas usianya belum diperbolehkan untuk mengendarai kendaraan, sebagaimana contoh pada uraian diatas anak musisi Ahmad Dhani yang mengendarai kendaraan dan terjadi kecelakaan mengakibatkan adanya korban.

Posisi orang tua seperti pada dua contoh kasus diatas dapat dikatakan turut serta atau bisa jadi perbantuan/membantu melakukan tindak pidana yang dilakukan anaknya, maka konsekuensinya orang tua juga bertanggung jawab terhadap tindak pidana tersebut yang dirinya sendiri sebagai subjek yang turut serta, bukan semata-mata peralihan pertanggungjawaban dari kesalahan anaknya saja. Dalam hukum pidana "perbuatan" 
mencakup 3 (tiga) hal meliputi melakukan sesuatu (commission), tidak melakukan sesuatu/pembiaran terhadap sesuatu (Ommission) dan akibat.

Pertanggungjawaban orang tua terhadap tindak pidana yang dilakukan oleh anak, yang mengindikasikan orang tua sebagai turut serta ataupun perbantuan ketentuan hukum yang unsur-unsurnya mendekati konsteks pada lazimnya posisi orang tua saat anak melakukan tindak pidana adalah Pasal 56 ayat (2) yakni berupa memberi kesempatan, sarana dan keterangan dan Pasal 57 ayat (3) dan (4) $\mathrm{KUHP}^{28}$, yakni pidana tambahan bagi perbantuan sama dengan kejahatannya sendiri dan penentuan pidana terhadap pembantu yang diperhitungkan hanya perbuatan yang sengaja dipermudah atau diperlancar beserta akibat-akibatnya. Akan tetapi dalam hal keterlibatan orang tua kepada penyertaan atau perbantuan tindak pidana belum dapat dipastikan anak yang melakukan tindak pidana tersebut benar-benar terlepas dari tanggungjawab pidana. Namun bila kita kembalikan kepada konteks awal, bahwa anak sebagai korban dari kelalaian orang tuanya sekaligus sebagai subjek yang tidak mampu

\footnotetext{
${ }^{28}$ Pasal 56 ayat (2) dan Pasal 57 ayat (3) dan (4) Kitab Undang-Undang Hukum Pidana
}

untuk dimintai pertanggungjawaban, maka jelaslah pertanggungjawaban menjadi beralih kepada orang tua karena anak juga dibawah penguasaan orang tuanya.

Meskipun dengan menggunakan ketentuan KUHP terdapat jalur peralihan pertanggungjawaban orang tua terhadap anak yang melakukan tindak pidana, namun berdasarkan observasi dalam tataran empiris, penyelesaian perkara tindak pidana yang dilakukan oleh anak dilakukan proses penyelesaiannya secara diversi, jenis penyelesaian perkara anak tersebut dipilih karena adanya Undang-Undang Peradilan anak yang merupakan Lex Specialis dari KUHP yaitu pada Pasal 1 angka (7) UU No. 11 tahun $2012^{29}$ Tentang Sistem Peradilan Pidana Anak mengenal istilah diversi yang didefinisikan sebagai pengalihan penyelesaian perkara anak dari proses peradilan pidana ke proses diluar pengadilan, selanjutnya Pasal 5 ayat $(3)^{30}$ dinyatakan bahwa dalam system peradilan pidana anak wajib diupayakan diversi. Kata "wajib" tersebut dapat dipahami suatu hal yang tidak dapat ditawar dan

\footnotetext{
29 Pasal 1 angka (7) Undang-Undang No. 11 Tahun 2012 Tentang Sistem Peradilan Pidana Anak.

${ }^{30}$ Pasal 5 ayat (3)Undang-Undang No. 11 Tahun 2012 Tentang Sistem Peradilan Pidana Anak.
} 
penekanan dari suatu hal yang harus pembaharuan KUHP hanya berarti dilaksanakan.

pembaharuan materi hukum pidana. ${ }^{32}$

Sistem hukum nasional sebagai suatu himpunan bagian hukum atau subsistem Bahkan harus disertai pula dengan hukum yang saling berkaitan yang membentuk pembaharuan budaya hukum masyarakat (legal culture reform) dan pembaharuan satu keseluruhan yang rumit atau kompleks tetapi merupakan satu kesatuan. ${ }^{31}$ Menurut struktur atau perangkat hukumnya (legal structure reform). ${ }^{33}$ Sedangkan menurut Friedmann, bahwa Menurut Friedmann, Sudarto, pembaharuan hukum pidana yang sistem hukum terdiri atas struktur hukum (structure), substansi/materi hukum (substance), dan budaya hukum (legal culture). Sehingga ketika berbicara pembaharuan sistem peradilan pidana dalam kajian legal policy, tidak hanya kebijakan Undang-undang, namun juga kebijakan yang berkaitan dengan struktur dan budaya hukum yang berkembang baik secara struktural maupun di masyarakat.

Sebenarnya pembaharuan hukum pidana tidak identik dengan pembaharuan KUHP. Pembaharuan hukum pidana lebih bersifat komprehensif dari pada sekedar mengganti KUHP. Pembaharuan hukum pidana meliputi pembaharuan dalam bidang struktur, kultur dan materi hukum. Sedangkan

31 Kusnu Goesniadhie, Harmonisasi Hukum Dalam Perspektif Perundang-Undangan (Lex Spesialis Suatu Masalah), Surabaya: JP Books, 2006, hal. 72. menyeluruh itu harus meliputi pembaharuan hukum pidana material, hukum pidana formal dan hukum pelaksanaan pidana.

\section{KESIMPULAN}

Berdasarkan uraian diatas dapat disimpulkan sebagai berikut:

1. Pertanggungjawaban Pidana Anak Sebagai Pelaku Tindak Pidana lalu lintas dengan Terpenuhinya syarat-syarat adanya pertanggungjawaban pidana seorang anak, hal ini berarti bahwa terhadap anak tersebut dapat dikenakan pemidanaan, pemidaan hendaknya harus memperhatikan perkembangan seorang

32 Ahmad Bahiej, Pembaharuan Hukum Pidana Indonesia. (Telaah atas Rancangan Kitab UndangUndang Hukum Pidana Indonesia), Makalah ini disampaikan pada kajian rutin Pusat Studi dan Konsultasi Hukum (PSKH) Fakultas Syari'ah IAIN Sunan Kalijaga Yogyakarta tanggal 29 Desember 2003.

33 Barda Nawawi Arief, Beberapa Aspek Kebijakan Penegakan dan Pengembangan Hukum Pidana, Citra Aditya Bakti, 1998, Bandung, hal. 133 
anak. Salah satu penyebab terjadinya tindak pidana kecelakaan lalu lintas khususnya bagi anak adalah tidak dipenuhinya syarat-syarat berlalu lintas sesuai ketentuan hukum yang berlaku, diantaranya memiliki SIM (Surat Izin Mengemudi) dan keterampilan mengendarai kendaraan bermotor. Untuk mendapatkan Surat Izin Mengemudi (SIM), pengemudi harus terlebih dahulu memenuhi persyaratan yang terdiri dari, persyaratan usia, administratif, kesehatan, dan lulus ujian. Hal ini seringkali diabaikan oleh para orang tua yang memiliki anak dan sudah berani mengendarai kendaraan bermotor. Undang-Undang Lalu Lintas dan Angkutan Jalan telah mengatur syaratsyarat tersebut dalam Pasal 81 sebagaimana telah disebutkan diatas. Anak yang terlibat dalam kecelakaan lalu lintas yang menyebabkan kematian korban harus mempertanggung jawabkan perbuatannya. Seorang anak harus bertanggung jawab atas kematian.

2. Pengalihan pertanggungjawaban pidana kepada orang tua dari anak yang melakukan tindak pidana Lalu Lintas tidak dapat ditemukan secara eksplisit dalam proses penyelesaian yang mengacu kepada Kitab Undang-Undang Hukum Pidana ataupun aturan hukum terkait dengan lalu lintas, tetapi apabila ditafsirakan dan dikontruksikan kembali orangtua dinyatakan melakukan perbantuan atau penyertaan terhadap tindak pidana yang dilakukan anaknya dan turut bertanggungjawab terhadap korban dari tindak pidana yang dilakukan oleh anaknya. Disamping itu anak juga bisa dikategorikan sebagai korban dalam artian korban dari kelalaian orang tuanya karena selama statusnya masih menyandang sebagai anak, maka ia masih dibawah penguampuan orangtua atau walinya. Terkait peralihan tanggungjawab anak yang melakukan tindak pidana kepada orangtua yang diaplikasikan melalui proses diversi. ketentuan ini mengacu pada UndangUndang Nomor 11 Tahun 2012 tentang Sistem Peradilan Pidana Anak, dari diversi tersebut menghasilkan bentuk pertanggungjawaban yang tidak melibatkan anak dengan sanksi pidana dan yang melakukan pertanggungjawaban terhadap kerugian yang diderita oleh korban adalah orang tua dari anak yang melakukan tindak pidana, seperti orang tua dibebankan terkait 
pidana tambahan berupa ganti kerugian Moeljatno, 2002, Asas-Asas Hukum Pidana, atau denda kepada korban.

Renika Cipta, Jakarta

Muladi dan Barda Nawawi Arief. 1992. Bunga Rampai Hukum Pidana, Bandung: Alumni.

Buku

Ali, Zainuddin. 2010. Metode Penelitian Hukum, Sinar Grafika, Jakarta.

Djamil, M. Nasir. 2013, Anak Bukan Untuk Dihukum, Sinar Grafika, Jakarta Timur

Goesniadhie, Kusnu. 2006. Harmonisasi Hukum Dalam Perspektif PerundangUndangan (Lex Spesialis Suatu Masalah), Surabaya: JP Books.

Gultom, Maidin. 2010. Perlindungan Hukum Terhadap Anak Dalam Sistem Peradilan Pidana Anak Di Indonesia, PT. Refika Aditama, Bandung.

Haar, Ter. dalam Syafiyudin Sastrawujaya. 1977. Beberapa Masalah Tentang Kenakalan Remaja, PT. Karya Nusantara, Bandung.

Hamzah, Andi. 1997. Asas-Asas Hukum Pidana, Rineka Cipta, Jakarta

Ibrahim, Johnny. 2010 Teori Dan Metodologi Penelitan Hukum Normatif, Bayumedia Publisshing, Malang.

Marzuki, Peter Mahmud. 2013. Penelitian Hukum, Edisi revisi, Kencana, Jakarta.

Meliala, A.Syamsudin dan E.Sumaryono. 1985. Kejahatan Anak Suatu Tinjauan dari Psikologis dan Hukum, Yogyakarta, Liberty.
Prodjodikoro, Wirjono. 2003. Asas-Asas Hukum Pidana di Indonesia. Bandung: Refika Aditama.

2003. Tindak-Tindak Pidana Tertentu di Indonesia, Bandung, Refika Aditama.

Schwartz, Ira M. dan laura Preiser. 1992. “ Diversion and Juvenile Justice: Can We Ever Get It Right? " dalam Restorative Justice on Trial : Pitfalls and Potentials of Victim Offender Mediation International Research Perspectives, eds Messmer,H dan Otto, H.U, Kluwer Academic Publischers, Dordrecht.

Soekanto, Soerjono dan Sri Mamuji. 1994. Penelitian hukum Normatif: Suatu tinjauan Singkat,Jakarta: Raja Grafindo Persada.

Soemitro, Ronny Hanitijo. 1990. Metedologi Penelitian Hukum dan Jurimetri, Ghalia Persada Jakarta.

Soetodjo, Wagiati. 2006. Hukum Pidana Anak, Bandung: PT Refika Aditama.

Sudarsono. 1991. Pengantar Ilmu Hukum, Rineka Cipta, Jakarta.

W.J.S, Poerwadarminta. 2003. Kamus Umum Bahasa Indonesia, Balai Pustaka, Jakarta. 
Wiyanto, Roni. 2012. Asas-asas Hukum Pidana Indonesia, Bandung, C.V Mandar Maju.

\section{Jurnal dan Makalah}

Ahmad Bahiej, Pembaharuan Hukum Pidana Indonesia. (Telaah atas Rancangan Kitab Undang-Undang Hukum Pidana Indonesia), Makalah ini disampaikan pada kajian rutin Pusat Studi dan Konsultasi Hukum (PSKH) Fakultas Syari'ah IAIN Sunan Kalijaga Yogyakarta

Chairul Bariah, Mohd. Din, Mujibussalim Syiah Kuala Law Journal : Vol. 1, No.3 Desember 2017

\section{Peraturan Perundang-Undangan}

Undang-Undang Nomor 11 Tahun 2012 tentang Sistem Peradilan Pidana Anak

Undang-Undang No. 11 Tahun 2012 Tentang Sistem Peradilan Pidana Anak.

Kitab Undang-Undang Hukum Pidana 